\title{
Compatibility of Analog Forestry and Conservation Agriculture as Strategies for the Sustainable Management of Forest Resources in Bui, NW Cameroon
}

\author{
Tsi Evaristus Angwafo, Kemkia Christian Danernyuy, and Mvo Denis Chuo
}

\begin{abstract}
This study entitle compatibility of analog forestry (AF) and conservation agriculture (CA) as strategies for the sustainable management of forest resources was carried out in Bui, NW Cameroon. The objective of the study was to examine the management schemes adopted by communities and compatibility between analog forestry and conservation agriculture that make them better strategies for forest resource management. Qualitative and quantitative designs were used during data collection. Data were analyzed descriptively and inferentially using statistical package for social sciences, cross tabulation and Microsoft excel. Result revealed that $\mathrm{AF}$ and $\mathrm{CA}$ are $80 \%$ compatible for the restoration of forest resources according to farmers responds. For instance, $20.6 \%$ and $17,2 \%$ of respondents reported that compatibility of $\mathrm{AF}$ and $\mathrm{CA}$ reduced pressure on natural forests and boost rehabilitate degraded forest and water shades respectively. Therefore, soil protection and anchorage through the establishment of tree species whilst maintaining cover and eliminating tillage with $\mathrm{AF}$ and $\mathrm{CA}$ are logical solution to rehabilitation and sustainable continuation of natural resources in Bui.
\end{abstract}

Index Terms-Analog Forestry, Bui, Conservation Agriculture, Sustainable Management

\section{INTRODUCTION}

Highlight Geographically, Cameroon is located virtually at the centre of Africa and near the Equator. This location endows her with many biodiversity potentials [1]. From south to north, there are various types of tropical mountain rainforests, humid savannah, gallery forests and dry forests [2. When the climate is drier, dry savannah, steppes and grassland prevail from the south to the north of the country as a result of the dry season that run from October to March in the south and October to June in the north. Apart from these natural ecosystems, there are also man-made agrosystems made of large Rubber Banana, Palm tree, Cocoa, and Coffee plantations [2].

In the study of villages in the dry regions of India,[3]Jodha(1990) finds that: "the rural poor obtain the

Published on June 14, 2020

E. A. Tsi, University of Dschang, Faculty of Agronomy and Agricultural Sciences, Cameroon (email: tsievaristus@yahoo.co.nz)

K. C. Danernyuy; University of Dschang, Faculty of Agronomy and Agricultural Sciences, Cameroon (email: ckemtia@yahoo.com)

M.D. Chuo, University of Dschang, Faculty of Science, Cameroon (email: mvo235@yahoo.com) bulk of their fuel supplies and fodder from the forest surrounding their communities. The collection of forest products is an important source of employment and income, especially during the periods when other opportunities are almost non-existent" [4] (Wettenhall and Penna, 2013). In many surveyed, forest have declined in both areal extent and productivity, with significant increases in the number of people per unit area of forest[5] (Senanayake and Jack, 1998). Much of this decline is due to extensive utilisation. Sometimes new production methods are not compatible with traditional uses of the resource; for example, commercial forestry may prevent the gathering of other forest products, and new management structures may exclude certain groups from forest access [6] and [7]. Access to and sustainable management of forest resources is therefore crucial in enhancing rural livelihoods[8]. The concept of "sustainable rural livelihoods" is increasingly taking a central stage in the debate about rural development, poverty reduction and environmental management,[9]This relates to a wide set of issues which encompass much of the broader debate about the relationship between poverty and the environment [10]. The result of this is that there is today an urgent need to produce sustainably greater harvests from the world's agriculture[11]. Hence making the judicious combination of the environmentally friendly practices of conservation agriculture (CA) and agroforestry (AF) as solid building blocks on the road to achieving this goal. [7].

Several issues emerge as a result of the exploitation of natural resources, especially, community forests resources [12]. In Bui Division these issues affect both the resource base and the physical state of the rural community. In relation to the resource base, there is over-exploitation of forests leading to deforestation and biodiversity depletion; According to [13], areas which used to have abundant submontane forest in the past can now be identified only from the appellation "Kov" which means "forest". Examples include Takov, Simon Kov, Kov-à-weh, Kuikov and KovNdzeen. In these areas, due to rapid and uncontrolled deforestation, not even a single natural tree exists except for grasslands and stretches of farms dotted with tree stumps. Furthermore, in 2003, fire data collected from the KilumIjim Forest revealed that fires affected eleven out of eighteen community forests, with the most extensive damage occurring at Bihkov (more than 1003ha affected), Nchiiy (655ha), Emfveh Mii (111ha) and Mbai (74ha). Also, in 2003 alone, there were forty-eight (48) separate fires devastating an area of $1944.17 \mathrm{ha}$, with $61 \%$ occurring in degraded areas, $32 \%$ in under graded habitats and $7 \%$ in grasslands (Annual Progress Report of Kilum-Ijim Forest, 2003). This therefore, is a serious threat to the biodiversity of montane forest in Bui-Division. 
If the above-mentioned problems are not addressed with vigor, then the population of this ecological zone might become "environmental refugees" in the future. The objective of the study therefore is to examine the community management scheme adopted by communities in Bui Division and examine compatibility between conservation agriculture and analog forestry that make them better strategies for forest resource management in Bui Division. The study hypothesized compatibility existing between CA and AF significantly led to increase forest resources of Bui and to develop a conceptual model for the sustainable exploitation and management of forest resources by the rural people.

\section{MATERIALS AND METHOD}

\section{A. The description of the case study area}

Bui Division is situated between latitudes $6^{\circ} 00^{\prime \prime}$ to $6^{\circ} 20^{\prime \prime}$ North of the Equator and longitudes $10^{\circ} 30^{\prime \prime}$ to $10^{\circ} 60^{\prime \prime}$ East of the Greenwich Meridian (Fig: 1). It is a huge orographic plateau within the Cameroon Volcanic Line (CVL) with spectacular mountainous landscape like Mount Oku $(3,011 \mathrm{~m}$ above sea level) and the Mbaw-Tikar Plains (about $900 \mathrm{~m}$ above sea level) [14]. It provides a major watershed for the Niger and Sanaga river systems. The Division has a total surface area of $2,795 \mathrm{~km} 2$ (Divisional Delegation of Lands, Bui, Kumbo), with Kumbo as its headquarters. It has six Sub Divisions namely: Kumbo Central (630 km2), Jakiri (675 km2), Nkum (375.3 km2), Nkor-Noni $(307.7 \mathrm{~km} 2)$, Mbiame $(575 \mathrm{~km} 2)$ and Elak-Oku (232 km2). Bui Division is bordered to the North by Donga and Mantung Division, to the North East by Boyo, East by Menchum, South East by Ngoketunja, and finally in the South West by the Noun Division which is in the Western Region.

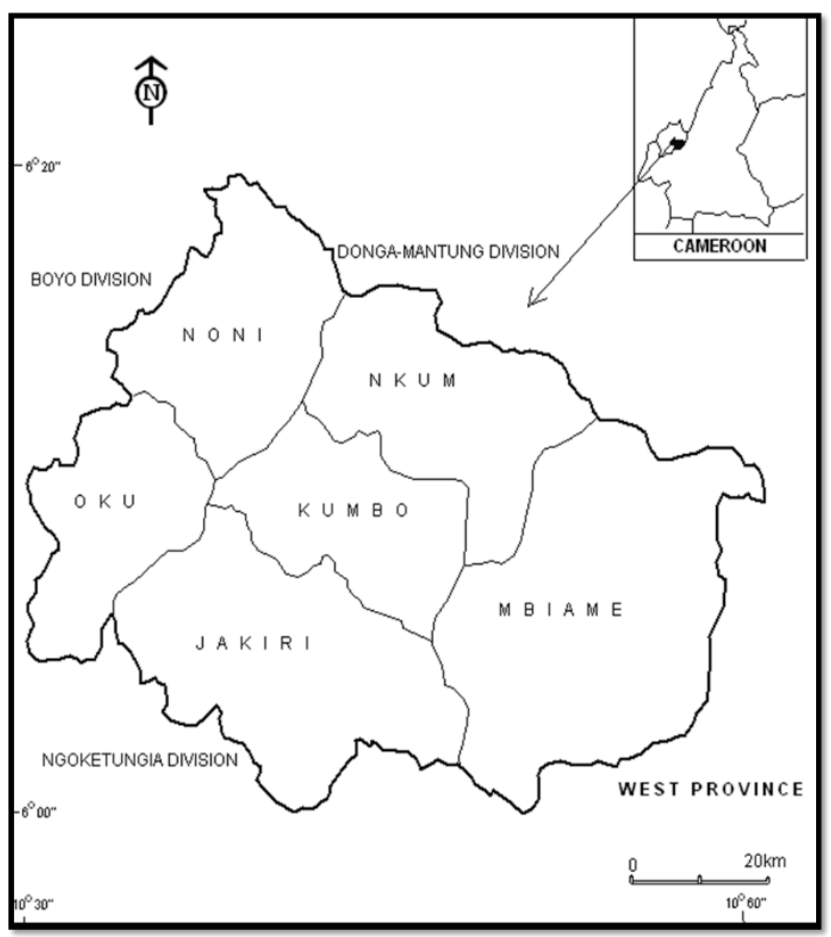

Fig 1: The map of Cameroon showing the location of Bui Division and her villages

Source: Realized from the Administrative Map of Cameroon, N.G.C., Yaounde, 1994
Bui Division is divided into four major vegetation types; the grasslands, wooded savannah, savannah with trees and shrubs, and forests (Fig.2). The dominant vegetation type in Bui Division is the Guinea-Sudano-Savannah type, though with some natural forests at Kilum, Mbinon, Nseh (Mbobo), Kovifem, Kovkinkaar, Kovnanan, Ndzeen, Mbokam, Kovtintosong. Therefore, the diversity of the Bui landscapes is also reflected in its vegetation. Although, typically a tropical savannah landscape, there are remnants of montane forests, which have been acting as sponges for water resources as well as biodiversity hotspots. This is the case of the Mount Oku region which is a main watershed in Bui Division. There are also vast areas of savannah (montane grasslands).

The montane forests have great hydrological significance. The Kilum Forest is the last remnant of Afro-montane forest in West Africa with its rare plants like Alchemilla ficheri, Podocarpus latifolius, Prunus africana, Rapaneame lanophoeos at high altitudes, and also, its prominent fauna of 14 montane bird species endemic to Cameroon. the Mount Oku forest for example harbours a crater lake with a volume of $126,300,000 \mathrm{~m}^{3}[14]$. Montane forest refugia are also basins and catchments for streams supplying many communities downstream and feeding drainage basins of the Benue and Atlantic systems.[15]. These montane forests, for example Kovifem, Vekovi and Kilum forests, also have strong cultural and ancestral significance for the people of Bui Division, and they are often referred to as the last shelters of the gods of the land'[15].

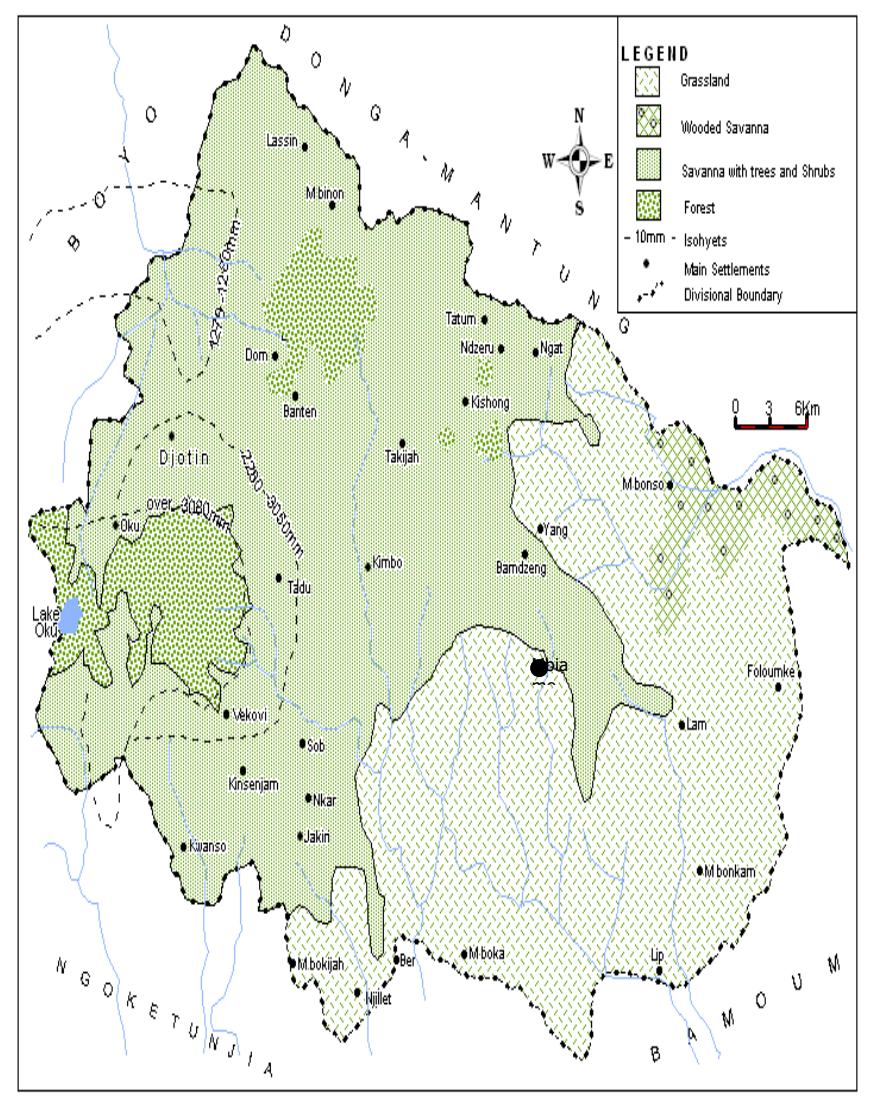

Fig. 2: Vegetation of Bui Division

Source: Adapted from the Map of Nkambe, NB-32-XVII; Field work, 2016

Generally, the remaining montane forests in Bui Division are under protection as community forests. These serve as 
sources of fuel wood, timber for construction, non-timber forest products (fibre) and medicinal plants in communities where they are found. In this respect, the exploitation of these resources leads to emerging environmental threats, that is, the degradation of montane forests, which in turn is the degradation of highland watersheds [1] and[16]. The Mount Oku region is a typical example.

\section{B. Methodology of Data collections}

Qualitative (descriptive) and quantitative designs were used in assessing the compatibility of conservation agriculture and analog forestry as strategies for the sustainable management of forest resources in Bui. The sampling procedure was purposive since the population is made up of those carrying out agriculture especially conservation agriculture and agroforestry. From each category simple random sampling technique was applied to select the respondents. The sample size was obtained using a percentage of the population from each sub-divisional headquarter. Therefore, 180 questionnaires were distributed to respondents as shown on table 1 below

TABLE 1 : DISTRIBUTION OF QUESTIONNAIRE PER SUBDIVISION IN BUI

\begin{tabular}{llll}
\hline $\begin{array}{l}\text { Sub- } \\
\text { division }\end{array}$ & $\begin{array}{l}\mathbf{2 0 1 5} \\
\text { projections }\end{array}$ & $\begin{array}{l}\text { census } \\
\text { proportion }\end{array}$ & questionnaires \\
\hline $\begin{array}{l}\text { Kumbo } \\
\text { central }\end{array}$ & 330862 & 52 & 94 \\
\hline Mbven & 28984 & 4 & 8 \\
\hline Noni & 30008 & 4 & 8 \\
\hline Jakiri & 118216 & 18 & 33 \\
\hline Oku & 131892 & 20 & 37 \\
\hline Total & 632,428 & 98 & 180 \\
\hline
\end{tabular}

Data were analyzed descriptively and inferentially using statistical package for social sciences, cross tabulation and MS Excel.

\section{RESULTS AND DISCUSSION}

\section{A. Compatibility of $C A$ and AF in Forest Restoration in Bui}

From the questionnairesurvey conducted to assess the compatibility of $\mathrm{CA}$ and $\mathrm{AF}$ in forest restoration, out of the 180 questionnaire administered, $157(87.2 \%)$ individuals attempted response to the questions. Table 2 below, shows the compatibility of $\mathrm{CA}$ and AF to forest restoration in Bui Division.

TABLE 2: COMPATIBILITY OF CA AND AF TO FOREST RESTORATION IN BUI DIVISION

\begin{tabular}{lll}
\hline Compatibility of CA and AF & Frequency & Percentage \\
\hline Reduced pressure on natural forests & 37 & 20.6 \\
\hline Species diversity & 24 & 13.3 \\
\hline Resource conservation & 29 & 16.1 \\
\hline $\begin{array}{l}\text { Rehabilitate degraded forest and water } \\
\text { shades }\end{array}$ & 31 & 17.2 \\
\hline $\begin{array}{l}\text { Carbon sequestration } \\
\text { Carbon dioxide from air) }\end{array}$ & 9 & 5.0 \\
\hline $\begin{array}{l}\text { Diversified products and Continuous } \\
\text { flow of products }\end{array}$ & 18 & 10.0 \\
\hline Shade & 4 & 2.2 \\
\hline Other & 5 & 2.8 \\
\hline Total & 157 & 87,2 \\
\hline Missing data & 23 & 100,0 \\
\hline Overall Total & 180 & \\
\hline
\end{tabular}

From table two above, shows that majority $(20,6 \%)$ of the respondents pointed out that the compatibility of $\mathrm{CA}$ and $\mathrm{AF}$ reduces pressure on natural forests, closely followed by those who said it help to rehabilitate degraded forest and water shades $(17,2 \%)$, improve resource conservation $(16,1 \%)$, species diversity $(13,3 \%)$, continuous flow of products $(10,0 \%)$, carbon sequestration $(5,0 \%)$ and diversified products shade $(2,2 \%)$. However, a very few respondents $(2,8 \%)$ did not response to the questionnaires.

The efficient practice of CA and AF reduces the pressure exerted by man on natural resources for his survival. This pressure is through exploitation of forest resource that range from timber to non-timber forest products like firewood, food (through hunting), medicine and cutting down of the trees to acquire land for agriculture. Result shows that, most of the farmers in Bui acknowledge that $\mathrm{CA}$ and $\mathrm{AF}$ can contribute greatly to the restoration of forest. This is based on the fact that these two practices provide forest products that people usually harvest from the forest but farmers now grow them in their own farms. Thus, natural forest can now grow with no disturbance and couples with the fact that trees grow together with crops profitably expanding forest within the community which agrees with the study of [17] and [18].

[19]Sebastian in 2015 indicated that; Both AF and CA provide enhanced habitat and support for biodiversity for macro and micro fauna. In the context of Bui, this has appeared to be true, $13.3 \%$ of the farmers, of the respondents agree that $\mathrm{CA}$ and $\mathrm{AF}$ techniques can increase species diversity. Fauna be it micro (worms and insects) or macro (mammals or reptiles) can only survive in completely forested areas.

In Bui division the practice of CA and AF has provided these possibility as farmers who have practice AF for over 5years confirm that they are able to hunt bush rats in their farms and they can see crops that have been cut down in their farms by chimpanzees that come to feed on fruits in their farms. From the interview carried out with the CENDEP officials, it showed that since the introduction of analog forestry by CENDEP in Bui since 2008, they have introduce over 47 tree species in the Mbiame communal and kitiwum water catchment increasing biodiversity of the areas.

$\mathrm{AF}$ and $\mathrm{CA}$ improve the conservation of soil, nutrients and water in the landscape. These components are the drivers that when not available in farms, push people to cut down forest in search for fertile soil because they only occur under forest conditions. By adopting $\mathrm{AF}$ and $\mathrm{CA}$, agricultural activities encroach into community forest areas and as such, soil and water conservation activities, for instance, establishing contours and ridging on steep slopes to reduce erosion and run-off, and the introduction of improved crop varieties, storage methods especially for potatoes, tomatoes, beans, maize, oil palm, bananas and plantains means that shifting cultivation can be prevented. As such, a more sedentary form of farming based on soil improvement on the same piece of land leads to conservation of the forest, since there is little or no clearing of virgin forest for farming.

AF is particularly well suited to the rehabilitation of land that has been degraded through wind and water erosion (often as a direct consequence of inappropriate and damaging mechanical tillage practices). AF is frequently judiciously combined with other agronomic practices that 
enhance the stabilizing and rehabilitating impact of trees and shrubs according to [19].

As already indicated, fire is a major problem, devastating huge hectares of forests in Bui Division. These fires occur mostly in the dry season. According to an interview granted to the FMC of Mbiame and Bihkov forest committee of Vekovi, it proved that annual fire tracing activities conducted around the forest through the cutting of dry grass and removing it from the boundary of the forests, and also clearing three- four meters outside the forest and catchment protects the forest.

Live fences of fast growing, often leguminous, trees (such astephrosia) also serve not only as fences for livestock and soil erosion control but also seed banks, sources of fodder and fuel wood and for fruit, flower and medicine production. The provision of fodder from tree crops can alleviate the pressure on crop residues so that they can be left as mulch in the CA system[20]. As has been noted, CA is best suited to well-managed, productive agricultural areas[21]. But this does not mean that the concepts cannot be used for land rehabilitation, they can. The principle of permanent soil cover is very appropriate to absorbing raindrop and wind energy and so reducing or eliminating wind and water erosion. No-till techniques also retain the soil in situ and so prevent particle detachment and erosion. The natural channel system built up by undisturbed soil biota promotes better water infiltration and so reduces runoff and floods. The strength of CA, however, is that it improves the sustainability of agricultural land use and conserves the available land resources[21]. By increasing soil productive capacity and crop productivity it reduces the pressure on land and this can be very important where unsustainable land use leads to abandonment and expansion into unsuitable areas which should be protected according to[22] Dumanski, 2006.

\section{$B$. Farmer's opinions on the compatibility between $C A$ and $A F$}

Farmer's opinions on the compatibility between CA and AF were clearly shown during to interview survey. Table 3 and figure 3 below, shows farmers' response on compatibility of $\mathrm{CA}$ and $\mathrm{AF}$ in forest restoration in Bui.

\begin{tabular}{|c|c|c|}
\hline $\begin{array}{l}\text { Response on compatibility of CA } \\
\text { and AF }\end{array}$ & Respondents & $\%$ \\
\hline Yes & 144 & 80,0 \\
\hline No & 24 & 13,3 \\
\hline Total & 168 & 93,3 \\
\hline Missing data & 12 & 6,7 \\
\hline Total & 180 & 100,0 \\
\hline
\end{tabular}

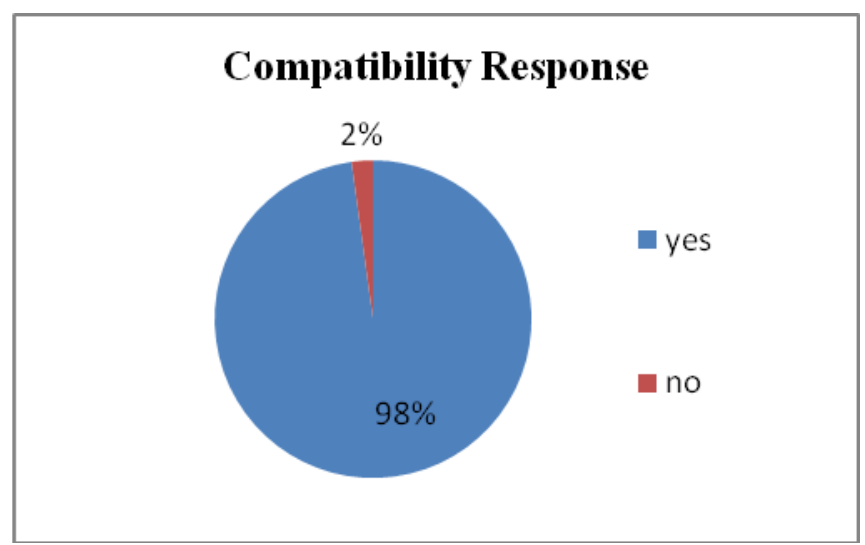

Fig 3: Forest restoration compatibility of $\mathrm{CA}$ and $\mathrm{AF}$

From table 3 and figure 3 above, $80 \%$ of the respondents supported forest restoration compatibility of CA and AF while $13.3 \%$ did not agreed to this practices as they still strongly attached to their traditional methods of cultivation.

This shows that farmers agrees with the norms that, a combination of plant species with complementary habit us can exploit resources in a given ecosystem more effectively than pure stands that compete for light in the same canopy stratum and for nutrients and water in the same soil layer when link to the study of Blank, 2008[23]. As in the climax stage of a natural forest ecosystem, multi-storey systems occupy all available niches and resources can be used most effectively. Optimizing use of natural resources is particularly relevant in developing countries, where fertilizer prices are often prohibitive [19].

\section{CONCLUSION}

With clearity from result, observation and interaction are more likely to create workable solutions than simple technology. This, has been viewed two sided in Bui division with farmers believing that $\mathrm{CA}$ and $\mathrm{AF}$ can restore forest resources and only a few individual standing contrary. This is further promoted by the fact that,the compatibility of CA and $\mathrm{AF}$ for the restoration of forest resources greatly help to reduced pressure on natural forests, rehabilitate degraded forest and water shades, improve resource conservation. However, to shift away from simply exploiting natural resources, it is necessary to actively design and re-create resource systems that can mimic nature in form and function (in the same way as $\mathrm{CA}$ and $\mathrm{AF}$ does). Finally, the exploration of the many facets of $\mathrm{CA}$ and $\mathrm{AF}$ in this work has led us to the following conclusions on the highly desirable compatibility that exists between the two connected paradigms:

* Both CA and AF seek to emulate natural recycling mechanisms and other ecosystem services (especially the elimination of soil erosion) found in forests.

* Both CA and AF promote soil health and biodiversity and so both will enhance soil fertility and hence its productive capacity.

* Degraded land is best rehabilitated with AF systems in conjunction with CA (which is better designed to perform under good soil conditions). Soil protection and anchorage through the establishment of tree species whilst maintaining cover and eliminating tillage with $\mathrm{CA}$ is a logical solution to rehabilitation. 


\section{CONFLICT OF INTEREST STATEMENT}

We declare that there is no conflict of interest regarding the publication of this paper.

\section{ACKNOWLEDGMENTS}

We will like to extend our sincere thanks to all those who contributed in one way or the other to the success of this work. We acknowledge the practical field support offered by the Bui people especially farmers during the research period.

\section{REFERENCES}

[1] Neba, A., 1999. Modern Geography of the Republic of Cameroon, 3rd edition. Neba Publishers, Bamenda, Cameroon.

[2] Foahom, B., 2001. Biodiversity Planning Support Programme Integrating Biodiversity into the Forestry Sector. Paper presented for an International Workshop on "Integration of Biodiversity in National Forestry Planning Programme". CIFOR Headquarters, Bognor, Indonesia, 13-16 August 2001.

[3] Jodha, N.S., (1990). "Rural Common Property Resources Contributions and Crisis".Economics and Political Weekly, June 20, A65-A78.

[4] Wettenhall, G., and Penna, I., 2013. Analogue Forestry in Practice in Sri Lanka. Australian Forest Grower.

[5] Senanayake, R. and Jack, J., 1998. Analogue Forestry: An Introduction. Monash Publications in Geography No. 49. Melbourne: Monash Print Services.

[6] Maggs, P., and Hoddinott, J., 1997.The Impact of changes in common property resource management on intra-household allocation. Food Consumption and Nutrition Division (FCND) Discussion Paper No. 34. International Food Policy Research Institute.Washington DC. USA.

[7] Sims, B., Friedrich .T., Amir, K., Kienzle, J., 2009. Agroforestry and Conservation Agriculture: Complementary practices for sustainable development; II World Congress of Agroforestry, Nairobi, Kenya

[8] FAO., 2006. Agriculture and Consumer Protection Department, Rome: $F A O<$ <ttp://www.fao.org/ag/magazine/0110sp.htm $>$.

[9] Friedrich, T., 2005. Why should the world be concerned about sustainable resourcemanagement in agriculture? III World Congress on Conservation Agriculture, Nairobi, October pp 3-7.

[10] FAO., 2015. Conservation Agriculture, Agriculture and Consumer Protection Department, Rome: FAO http://www.fao.org/ag/cal

[11] Nyende, P., Nyakuni, A., Opio, John P., Odogola, W., 2007. Conservationagriculture: a Uganda case study.Nairobi. African Conservation Tillage Network, Centre de Coopération Internationale de Recherche Agronomique pour le Développement, Foodand Agriculture Organization of the United Nations

[12] Hauswirth D., Pham T.S., Nicetic O., Tivet F., Le Quoc D., Van de Fliert E., Kirchhof, G., Boulakia S., Chabierski S., Husson O., Chabanne A., Boyer J., Autfray P., Lienhard P., Legoupil J.-C., Stevens M. L. (eds) 2012. Conservation Agriculture and Sustainable Upland Livelihoods.Innovations for, with and by Farmers to Adapt to Local and Global Changes -Proceedings of the $3^{\text {rd }}$ International Conference on Conservation Agriculture in Southeast Asia. Held in Hanoi, Vietnam, 10th-15th December 2012.CIRAD, Montpellier, France; NOMAFSI, PhuTho, Viet Nam; University of Queensland, Brisbane, Australia. 372 p.

[13] Njilla, R.M.N. 2000. Land Use Effects on Surface Water Systems in Kumbo Central Sub Division, North WestProvince. Undergraduate dissertation, Department of Geography.

[14] Ndenecho, E.N., 2005. Biological Resource Exploitation in Cameroon.From Crisis to Sustainable Management. Unique Printers, Bamenda.

[15] Lambi, C.M. 2001. "Revisiting the Environmental Trilogy: Man, Environment and Resources". In Lambi, C.M. (Ed): Environmental Issues: Problems and Prospects. Unique Printers, Bamenda. PP. 105 $-117$.

[16] Naudin, K., Husson, O., Rollin D., Guibert, H., Charpentier, H., Abouabba, A, Njoya, A., Olinaj, P., Seguy, 1., 2010. Conservation agriculture adapted to specific conditions -No tillage for smallholder farmers insemi-arid areas (Cameroon and Madagascar).

[17] Dufty, A.C., 1998. Analogue Forestry. From little things, big things grow revegetation guide for the South West Slopes. Department of Land and Water Conservation, New South Wales.

[18] Dickinson, A. K., 2014. Analog Forestry: Creating Productive Landscapes. ETFRN News 56: November 2014. International Analog Forestry Network, San Jose, Costa Rica.
[19] Sebastian, K., Fischer, G., and Nachtergaele, F., 2015."Appropriate Agroecological Zones: Tropical Warm Subhumid, Tropical Warm, Semi-Arid Agro-Ecological Zones in SSA", HarvestChoice/IFPRI<http://droppr.org/data/map/aez09ssa>.

[20] Hobbs, P.R., Gupta, R., and Sayre, K., 2008. "The Role of Conservation Agriculture in Sustainable Agriculture", Philosophical Transactions of The Royal Society, Biological Sciences, vol. 363, pp. 543-555.

[21] Neelam C., Saharawat Y.S., and Sivaram V., 2013. Conservation Agriculture: An Option to Enhance Pollinators and Sustainability.World Journal of Agricultural Sciences 9; IDOSI Publications.

[22] Dumanski, J., Peiretti, R., Benetis, J., McGarry, D., and Pieri, C., 2006. The Paradigm of Conservation Tillage. Proceedings of World Association of Soil and Water Conservation Paper No. P1-7, 58-64.

[23] Blank, D., Goddard, T., Zoebisch, M., Gan, Y., Ellis, W., Watson, A., and Sombatpanit, S., 2008. No-till farming systems; A fresh look at life below the surface. Bangkok. World Association of Soil. pp73-81 